\title{
What Is the Cause of Graduates' Unemployment? Focus on Individual Concerns and Perspectives
}

\author{
Youngsik Hwang (Corresponding author) \\ Higher Education \& Student Affairs, Indiana University \\ 107 S Indiana Ave, Bloomington, IN 47405, USA \\ Tel: 1-812-318-4072_E-mail: yh27@indiana.edu
}

Received: June 12, 2016 Accepted: July 24, 2017 Published: August 1, 2017

doi:10.5296/jei.v3i2.11378ＵRL: https://doi.org/10.5296/jei.v3i2.11378

\begin{abstract}
The graduate unemployment rate is one of the current issues being discussed by higher education scholars. College students spend their time and money in order to receive educational advantages unavailable to high school graduates. So if they face unemployment, they are more vulnerable to unfavorable economic conditions because they have already spent their resources pursuing higher education. This paper examines the reasons why college graduates are facing unemployment in the competitive market. There are several factors that explain their unemployment status, and this paper identifies each component at an individual level. With specific analysis of the unemployment phenomena, this paper provides direction for further research.
\end{abstract}

Keywords: Higher education, Graduates, Unemployment

\section{Introduction}

The main goal of higher education has been focused on college access for college-aged students and gaining more admission for minority students. However, recently the target has moved toward achieving more successful college completion rate during President Obama's tenure. As a result, postsecondary education institutions are required to meet more diverse needs from emerging student cohorts like non-traditional students. Meanwhile, students pursue higher education for different educational objectives, and students select institutions for various reasons (Bastedo \& Gumport, 2003). Among these diverse purposes, economic perspectives emphasize the importance of educational outcomes after graduation based on future income. With the belief that more education reduces the possibility of unemployment, Brunello (2001) argues the role of higher education is as a training center for future workers. Bridgstock (2009) explains that elements of training college students for future employment 
include career management, employability, and discipline-specific skills. Despite this training, students sometimes delay graduation, and Arkes (2010) argues the reason for this extended schooling is fear of unemployment due to poor economic conditions.

College students normally attend their institution and graduate within a certain time frame. While graduates want to have acceptable incomes based on return of investment, they sometimes face unemployment after graduation. Unemployment is detrimental to the individual because it leads to financial deficits based on college debts and educational expenses. If graduates do not have the skills to meet the needs of employers, then the unemployment rate will increase unnecessarily. This study shows how graduates deal with unemployment and how they escape from it. While offering several policy suggestions, the following section describes graduate unemployment as a whole and interprets its related components.

\section{Conceptual Framework}

Higher education plays a critical role in training future community members based on social demands. After finishing their college education, graduates expect they will find a higher valued job compared to those of high school graduates, and the extension of unemployment has a negative effect on the wellbeing of individuals (Winkelmann, 2009). The fear of unemployment influences how students plan for their careers because college students sometimes consider studying beyond their senior year, and they tend to select majors in the natural sciences, rather than in the humanities or other social sciences (Bedard \& Herman, 2008; Gerardi, Herkenhoff, Ohanian, \& Willen, 2013). Thus graduates find themselves in a complicated decision-making process influenced by diverse external environmental factors. These factors include market conditions, issues of over-education, individual perspectives, and employable skills and abilities. College students preparing for graduation are affected by these components when planning for their career, networking and collecting useful information about the employment market (Cai, 2013). However, two students who select the same major will not necessarily have the same job opportunities, and their expected returns after graduation may also differ (Carnevale \& Cheah, 2013). In this aspect, college students are required to be more careful in preparation in order to lessen risk of unemployment in the future. Although those who are more educated have more opportunities related to job searching, training, and information, college graduates are still struggling to survive in the job market (Cairo \& Cajner, 2016).

\subsection{Market Condition: How the Market Affects Graduate Unemployment}

High school seniors decide whether or not they will attend college based on their desired career path. When students consider their college education, they cannot always accurately predict their career paths, and so they rely on information from sources such as parents, teachers, peer-groups. Under this uncertainty, the students select their institution with the expectation of high financial return after graduation, and they spend educational expenses during college life. These expectations correlate with reality more often during a period of economic boom, when the market requires more workers to be hired in order to produce additional output, and higher education institutions play a role in providing well-trained 
future labor forces at that time. However their expected returns may not be satisfied during an economic recession, when workers are laid off (Shapiro, Dundar, Wakhungu, Yuan, Nathan, \& Hwang, 2016). Nevertheless, the re-employment rate of educated workers is still higher than that of their less-educated counterparts (Riddell \& Song, 2011) Through the education system, people can acquire useful employable skills that can help them overcome the unfavorable market conditions (Rae, 2010; Naong, 2011; Mbah, 2014). Thus students who are facing uncertainty during economic recession reconsider their future career path to meet flexible environment (Chen, Kannan, Trehan, \& Loungani, 2011). These uncertain situations affect graduates' expectations of future return. Uncertainty and expectation both contribute to the measurement of the possibility of employment, and the searching costs work as a cost-side variable in the process. Market conditions play a different role in affecting the employment opportunity as well. In this aspect, the problem is succinctly expressed like this,

$$
\text { Graduate unemployment }=f(\mathrm{x}, \mathrm{u}, \mathrm{s}) \cdot g(\mathrm{M})
$$

In terms of individual components, graduate unemployment can be a function of expectation (e), uncertainty (u), and searching costs (s). In other words, the graduates are sensitive to the fluctuation of expected return after graduation, and flexible market conditions affect the expected outcomes as an important determinant. The level of uncertainty includes the possibility of an economic recession and policy changes. Searching costs cover various indirect interactions related to job placement, as well as direct costs such as application fees. With those individual factors influencing finding proper job placement, the market condition (M) causes students to behave differently. For example, college students can delay their graduation to avoid an unfavorable labor market, while they eagerly graduate to meet favorable external labor demands. With economic fluctuation, workers experience transitions between employment, unemployment, and non-participation (Kroft, Lange, Notowidigdo, \& Katz, 2016). Even though graduates have sufficient skills and abilities to participate in the workplace, the market blocks their inflow. In sum, graduates are influenced by external market changes, as well as their own personal characteristics.

\subsection{Overeducation: Mismatching Supply/Demand}

One reason why graduates are unemployed is over-education in the labor market. From an economic perspective, being over-educated is exemplified in graduates who exceed the socially optimal level of education. So, if there are 100 available job positions that require bachelor-level skills and there are 100 graduates meeting the job requirements, the socially optimal status in the job market is achieved. Each student within the job placement requires certain academic attainments by each type. Prior economic studies have focused on structural unemployment, which comes from natural mismatching between available jobs and workers based on job mobility and wage bargaining cost (Herz \& Van Rens, 2011). Meanwhile the surplus of graduates who have advanced degrees can be considered in a more practical law of supply and demand in the labor market. The overeducated search for their future job based on their education level. According to the law of labor supply and demand, they should get a job regardless of their educational attainment. It is at this point that conflicts occur. While the group wants to earn more returns to balance educational costs, ordinary workplaces that 
require lower educational requirements do not provide sufficient salaries or benefits to make up for the opportunity cost of education. Ironically, students' efforts to receive a higher return in the job market result in their removing themselves from the pool for stable job placement. The gap between the labor supply and labor demand creates unemployment (Figure 1). The part of unemployed graduates (part (a)) can come from the over-educated cohort, which affects their earnings negatively, although they find employment later because of the law of supply and demand (Dolton \& Silles, 2008)

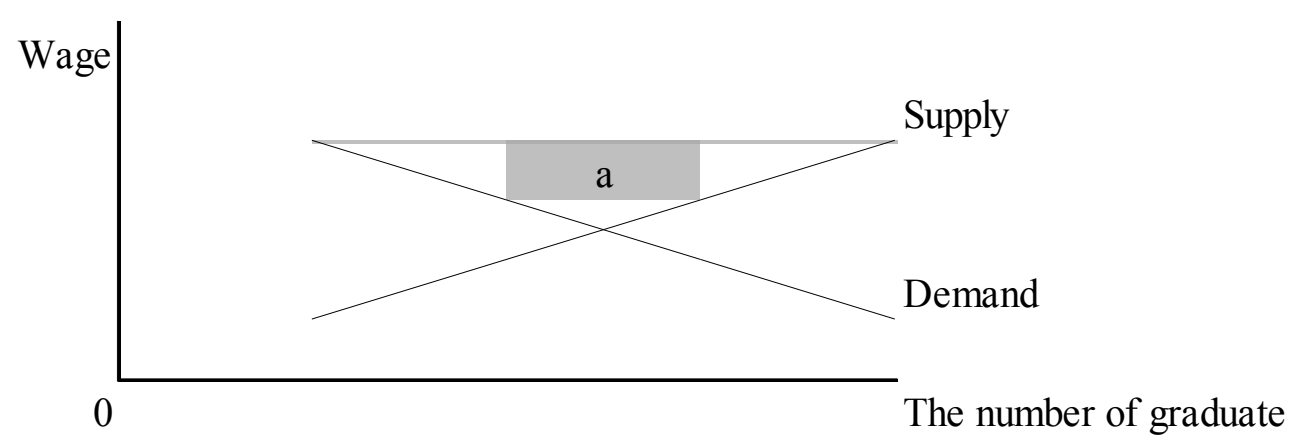

Figure 1. The effect of overeducation in the labor market

While all students experience the effects of a surplus of labor in the market, those who are overeducated face a different situation than their counterparts who have proper education levels. The latter have a more flexible attitude and tend to apply for lower benefits and returns because their expectation and sunken costs from their educational costs are lower than the overeducated group. These differences allow this group to find a job more easily. Furthermore, for the overeducated it means members of the group may be older and have more college debt, and thus have a more serious financial problem than their counterparts.

Supply (wage, market condition) $=$ Demand (wage, education, number of graduates)

The equation (2) above provides a general equilibrium between labor supply and labor demand, excluding other relevant indicators. While the real wage plays an important role in deciding the equilibrium of labor supply and demand in the market, education-related components such as education level and number of graduates have a significant effect on the level of hiring. Overeducated applicants distort the natural stream of optimal matching of individual workers for potential companies, which weakens the role of the autonomous actor.

\subsection{Imbalance between Individual Perspectives and Reality}

When graduates consider their next step after graduation, their expectation and plans play an important role in deciding their actions. They interact with other sources of influence such as peer-groups and faculty members to decide their future career. These social interactions across neighboring areas spill over into their internal decision-making process (Topa, 2001). Relevant authorities or parties also help them plan or take appropriate actions in the job 
market, and governmental engagement through education and training system guides graduates in career planning (Shamsuddin, Isa, Aziz, Mahfol, \& Alagari, 2013). McKeown and Lindorff (2011) point out that institutions have a responsibility to provide useful career services, however their findings suggest graduates find employment opportunities as a result of their own efforts, rather than through institutional supports.

College students accumulate knowledge and information about career paths during their academic career, and through this process, they formulate their own perspectives and expected outcomes. While major and institutional curricula provide useful skills, job opportunities and expected returns differ based on individual circumstances, especially if the chosen major is connected with particular occupations and industries. The market requires different sizes of labor forces to meet social needs and internal requirements. For example, emerging majors such as those in health care indicate a relatively low unemployment rate compared to that of traditional humanities and liberal arts majors (Carnevale, Cheah, \& Strohl, 2013). So graduates who have different majors want to get a job at same time, their job searching can have different outcomes depending on the demands of the market.

Through the training and learning process, college students narrow the gap between the expectation of return and the reality after graduation. However, the employer's perception of the graduates sometimes exists beyond their preparation. While higher education is a production line for work-ready graduates, practical employers think about the graduate's outcomes differently. Lowden, Hall, Elliot, and Lewin (2011) explain the employer's perception of employability skills of new graduates through several concepts. Work-related programs, such as internships, that institutions provide do not suffice as practical employability (Allison, Harvey, \& Nixon, 2002). Depending on individual majors and academic backgrounds, such programs may be insufficient to raise a student's level of employability, and employers are often suspicious about whether or not the institution provides proper administrative support during the program. These differences in perception between graduates and employers cause unemployment.

\subsection{Skills and Ability to Hire}

The gap between students' developed skills and ability on campus and practical job requirements can be another reason for unemployment. Securing a job depends not only on their academic performances, but also on personal background. Race, gender, and socioeconomic also play a certain role in whether an applicant is hired (Morley, 2001). In addition, the skills and experiences gained through college curriculum are sometimes not sufficient for entry-level positions (Pauw, Bhorat, Goga, Mucube, Oosthuizen, \& Van der Westhuizen, 2006). Sometimes education is limited to a general level, which does not provide the specific skills needed to be hired (Pawy, Oosthuizen, \& Van Der Westhuizen, 2008). Traditional curricula that the school provides do not match the practical needs in society, and those differences contribute to unemployment (Sparber \& Fan, 2012). Compared to two-year institutions or vocational colleges, four-year institutions provide a broader curriculum in order to develop advanced citizens, and their course design and structure tends to focus more on this mission. In this aspect, work experience or practical ability of graduates can be 
ignored by the institution, even though consideration of employers' needs in the degree course design and delivery should be important (Mason, Williams, \& Cranmer, 2009). The vocational education and training system combines work experiences, and general education guarantees the adaptation of a country's social need and institutional contexts (Zimmermann, Biavaschi, Eichhorst, Giulietti, Kendzia, Muravyev, \& Schmidl, 2013). In other words, the market requires both a sufficiently trained labor force and accurate perceptions of the market's demands to create the conditions for proper job placement. And then the market shares the information for employment across actors. Graduate competency and employability are connected with two concepts: firms' needs and personal attainment (Teijeiro, Rungo, \& Freire, 2013). The professionality measures how employable a graduate is and the effort to meet a firm's job requirement is essential to be hired after graduation.

\section{Comprehensive Model}

Although many factors explain graduates' unemployment, the four concepts discussed above involve multi-dimensional aspects of the issue (Figure 2). These factors are representative components that describe the graduates' unemployment at the individual level because they reflect diverse entities' interaction including institution, external environment, and the individual's attitude though psychological and physical aspects. While the graduates begin their college education with diverse educational goals and life plans, their career paths after graduation ultimately interact with aspects of the external environment such as the job market. These variable external factors sometimes affect the graduates' future planning or influence them to go into different fields. The complicated interactions between these components account for unemployment in society, and so prospective graduates should consider decreasing the gaps between their ideal career goals and actual possible employability to avoid unemployment in the future.

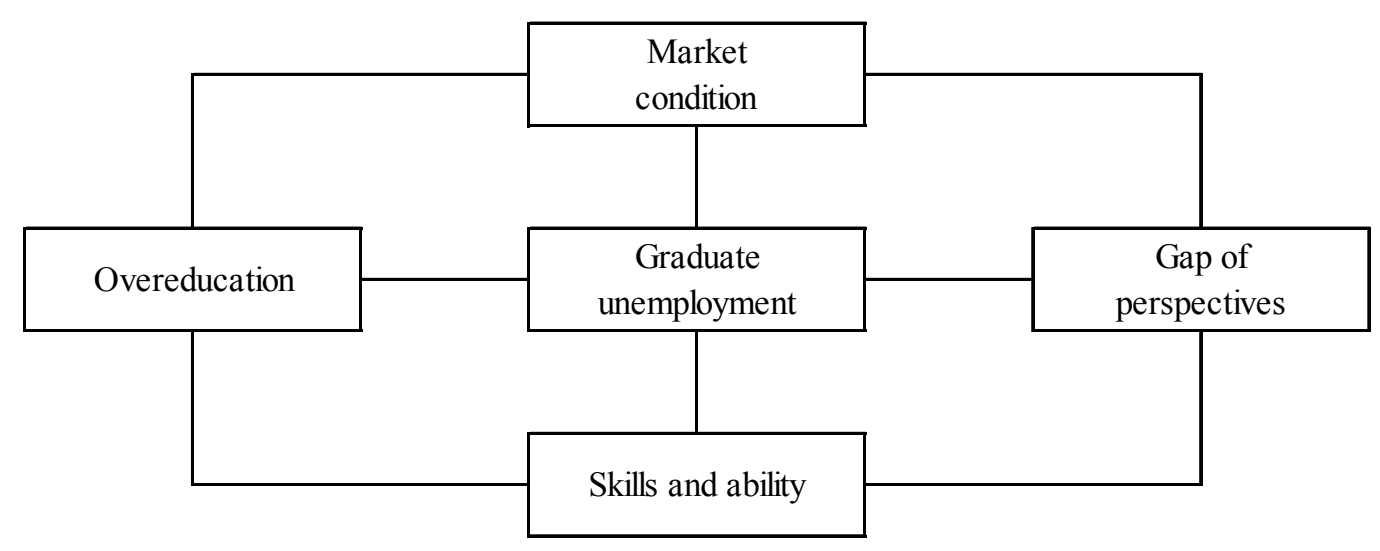

Figure 2. The factors around graduate unemployment

Graduate unemployment is not only an individual problem, but one that connects with other social issues such as crime, poverty, and life satisfaction. So a comprehensive consideration 
of society is required to solve the unemployment problem. Although graduates have accumulated proper skills and abilities through their college education, the market may not accommodate them based on available capital. In order to improve the rate of unemployment, collaboration between individual and society is required.

\section{Conclusion}

College students form a career plan during their school life and try to follow it after graduation. Becoming a competent worker in society is the first step in demonstrating their ability, and the transition from student to worker through schooling is a positive cycle for a sustainable society. Well-educated workers contribute to resolving social issues and create a sound foundation of social standard. Furthermore, proper hiring by a company allows society to fill any unmet needs such as college debts and poverty. This paper provides several factors to explain the graduates' unemployment at the individual level, and the four main factors play a role in providing evidence as to why graduates are unemployed. While over-education is due to redundant educational services from institutions, the gap in individual perspective is related to the preferences and priorities of the individual. In consideration with the market factors, the combination of both components is necessary to fully understand the issue of unemployment.

Although this paper focuses more on the individual causes related to graduate unemployment, society can provide other opportunities to hire additional graduates through different systemic changes. Further research is needed to investigate the role of society to lessen graduate unemployment. The government should create effective worker management strategies from public areas, and private sectors also need to create hiring plans in order to employ potential workers after graduation. Collaboration between public sector and private sector is necessary to handle the unemployment problem as a whole.

\section{Acknowledgements}

I thank Abigail Gipson at Indiana University who provided insight and expertise that greatly assisted the research, although any errors are my own and should not tarnish the reputation of the esteemed person. I would also like to show my gratitude to the reviewers for their valuable insights.

\section{References}

Allison, J., Harvey, C., \& Nixon, I. (2002). Enhancing employability: a long term strategic challenge. LTSN Generic Centre.

Arkes, J. (2010). Using unemployment rates as instruments to estimate returns to schooling. Southern Economic Journal, 76(3), 711-722. https://doi.org/10.4284/sej.2010.76.3.711

Bastedo, M. N., \& Gumport, P. J. (2003). Access to what? Mission differentiation and academic stratification in US public higher education. Higher Education, 46(3), 341-359. https://doi.org/10.1023/A:1025374011204

Bedard, K., \& Herman, D. A. (2008). Who goes to graduate/professional school? The 
importance of economic fluctuations, undergraduate field, and ability. Economics of Education Review, 27(2), 197-210. https://doi.org/10.1016/j.econedurev.2006.09.007

Bridgstock, R. (2009). The graduate attributes we've overlooked: Enhancing graduate employability through career management skills. Higher Education Research \& Development, 28(1), 31-44. https://doi.org/10.1080/07294360802444347

Brunello, G. (2001). Unemployment, education and earnings growth.

Cai, Y. (2013). Graduate employability: A conceptual framework for understanding employers' perceptions. Higher Education, 65(4), 457-469. https://doi.org/10.1007/s10734012-9556-X

Cairo, I., \& Cajner, T. (2016). Human capital and unemployment dynamics: Why more-educated workers enjoy greater employment stability. The Economic Journal.

Carnevale, A. P., \& Cheah, B. (2013). Hard Times 2013: College Majors, Unemployment, and Earnings.

Carnevale, A. P., Cheah, B., \& Strohl, J. (2013). Hard times: College majors, unemployment and earnings: Not all college degrees are created equal.

Chen, J., Kannan, P., Trehan, B., \& Loungani, P. (2011). New evidence on cyclical and structural sources of unemployment.

Gerardi, K., Herkenhoff, K. F., Ohanian, L. E., \& Willen, P. (2013). Unemployment, negative equity, and strategic default.

Groenqvist, H. (2011). Youth unemployment and crime: New lessons exploring longitudinal register data.

Herz, B., \& Van Rens, T. (2011). Structural unemployment. Economics Working Papers, 1276.

Kimerling, R., Alvarez, J., Pavao, J., Mack, K. P., Smith, M. W., \& Baumrind, N. (2009). Unemployment among women: Examining the relationship of physical and psychological intimate partner violence and posttraumatic stress disorder. Journal of Interpersonal Violence, 24(3), 450-463. https://doi.org/10.1177/0886260508317191

Kroft, K., Lange, F., Notowidigdo, M. J., \& Katz, L. F. (2016). Long-term unemployment and the great recession: the role of composition, duration dependence, and nonparticipation. Journal of Labor Economics, 34(S1), S7-S54. https://doi.org/10.1086/682390

Lowden, K., Hall, S., Elliot, D., \& Lewin, J. (2011). Employers' perceptions of the employability skills of new graduates. London: Edge Foundation.

Marginson, S., \& Rhoades, G. (2002). Beyond national states, markets, and systems of higher education: A glonacal agency heuristic. Higher Education, 43(3), 281-309. https://doi.org/ 10.1023/A:1014691304966

Mason, G., Williams, G., \& Cranmer, S. (2009). Employability skills initiatives in higher 
education: what effects do they have on graduate labour market outcomes? Education Economics, 17(1), 1-30. https://doi.org/10.1080/09645290802028315

Mbah, M. F. (2014). The Dilemma of Graduate Unemployment within a Context of Poverty, Scarcity and Fragile Economy: Are there Lessons for the University? International Journal of Economics and Finance, 6(12), 27. https://doi.org/10.5539/ijef.v6n12p27

McKeown, T., \& Lindorff, M. (2011). The graduate job search process-A lesson in persistence rather than good career management? Education+ Training, 53(4), 310-320. https://doi.org/10.1108/00400911111138479

Morley, L. (2001). Producing new workers: Quality, equality and employability in higher education. Quality in Higher Education, 7(2), 131-138. https://doi.org/10.1080/1353832012 0060024

Naong, M. N. (2011). Promotion of entrepreneurship education-A remedy to graduates and youth unemployment-A theoretical perspective. Journal of Social Sciences, 28(3), 181-189.

Pauw, K., Bhorat, H., Goga, S., Mncube, L., Oosthuizen, M., \& Van Der Westhuizen, C. (2006). Graduate unemployment in the context of skills shortages, education and training: Findings from a firm survey.

Pauw, K., Oosthuizen, M., \& Van Der Westhuizen, C. (2008). Graduate Unemployment In The Face Of Skills Shortages: A Labour Market Paradox1. South African Journal of Economics, 76(1), 45-57. https://doi.org/10.1111/j.1813-6982.2008.00152.x

Rae, D. (2010). Universities and enterprise education: responding to the challenges of the new era. Journal of Small Business and Enterprise Development, 17(4), 591-606. https://doi.org/10.1108/14626001011088741

Reimer, D., \& Jacob, M. (2011). Differentiation in higher education and its consequences for social inequality: introduction to a special issue. Higher Education, 61(3), 223-227. https://doi.org/10.1007/s10734-010-9373-z

Riddell, W. C., \& Song, X. (2011). The impact of education on unemployment incidence and re-employment success: Evidence from the US labour market. Labour Economics, 18(4), 453-463. https://doi.org/10.1016/j.labeco.2011.01.003

Shamsuddin, A., Isa, K. H. M., Aziz, M. N., Mahfol, N. Z. N. M., \& Alagari, T. (2013). Graduate unemployment: The awareness and perception of graduates towards government's initiatives. International Journal of Business, Economics and Law, 3(1), 15-24.

Sparber, C., \& Fan, J. S. (2012). Unemployment, Skills, and the Business Cycle Since 2000.

Teijeiro, M., Rungo, P., \& Freire, M. J. (2013). Graduate competencies and employability: The impact of matching firms' needs and personal attainments. Economics of Education Review, 34, 286-295. https://doi.org/10.1016/j.econedurev.2013.01.003

Topa, G. (2001). Social interactions, local spillovers and unemployment. The Review of Economic Studies, 68(2), 261-295. https://doi.org/10.1111/1467-937X.00169 


\section{Macrothink}

Winkelmann, R. (2009). Unemployment, social capital, and subjective well-being. Journal of Happiness Studies, 10(4), 421-430. https://doi.org/10.1007/s10902-008-9097-2

Zimmermann, K. F., Biavaschi, C., Eichhorst, W., Giulietti, C., Kendzia, M. J., Muravyev, A., ... Schmidl, R. (2013). Youth unemployment and vocational training. Foundations and Trends ${ }^{\circledR}$ in Microeconomics, 9(1-2), 1-157. https://doi.org/10.1561/0700000058

\section{Copyright Disclaimer}

Copyright for this article is retained by the author(s), with first publication rights granted to the journal.

This is an open-access article distributed under the terms and conditions of the Creative Commons Attribution license (http://creativecommons.org/licenses/by/3.0/). 